p-ISSN. 2086-9029

e-ISSN. 2654-5675

Vol. 22 No. 2, HIm. 159-352, Desember 2020

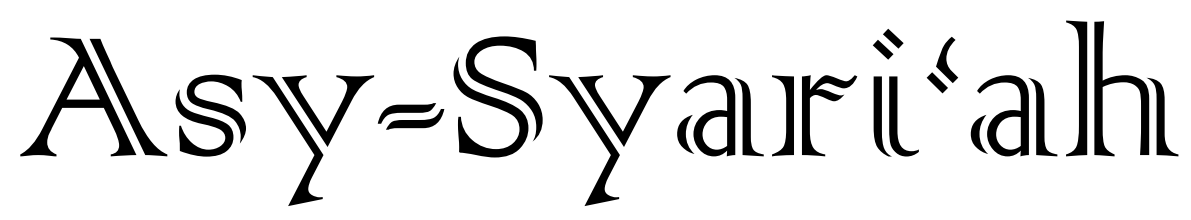

- Implementasi Prinsip Keadilan dalam Hukum Perjanjian Syari'ah

$(159-178)$ Zaenudin Mansyur

- Akad Rahn Tasyjili pada Gadai Tanah Pertanian di Pegadaian Syariah

$(179-196)$ Rahmadi Indra Tektona, Dyah Ochtorina Susanti

- Potensi Sertifikasi Halal dalam Mengahadapi Masyarakat Ekonomi

$(197-218)$ ASEAN

Deviana Yuanitasari, Helitha Noviana Dewi

- Akad Mudharabah sebagai Instrumen Pendanaan dan Pembiayaan di

$(219-236)$ Lembaga Keuangan Syariah

Asep Dadang Hidayat, Moh. Sar'an

- Praktik Rekayasa Dispensing Pump SPBU Persfektif Peraturan

$(237-258)$ Perundang-Undangan dan Hukum Islam

Hazar Kusmayanti, Ratu Chairunissa

- Dinamika Penerapan Akad Syariah dalam Produk Keuangan di Bank

$(259-274)$ Syariah

Jaenudin

- Etika Bisnis Islam pada Perilaku Pemasaran dan Kepuasan Konsumen

$(275-290)$ Wida Ramdania

- Kebijakan Fiskal Islam pada Masa Al-Khilafah Al-Islamiyah

Supriatna, Dedah Jubaedah

- Pelanggaran Prinsip Tanggungjawab Perusahaan Asuransi Investasi Persfektif Perundang-Undangan dan Hukum Ekonomi Syariah

Yoghi Arief Susanto, Yeti Sumiyati

- Identifikasi Kebutuhan Pembiayaan Syariah Peternak Lembu di Deli (337-352) Serdang

Marlya Fatira AK, Anriza Witi Nasution, Tuti Kurnia

FACULTY OF SHARIA AND LAW

STATE ISLAMIC UNIVERSITY SUNAN GUNUNG DJATI BANDUNG-INDONESIA IN COLLABORATION WITH ASOSIASI SARJANA SYARIAH INDONESIA 


\section{Asy-Syari'ah}

Volume 22, Number 2, 2020

\section{EDITOR-IN-CHIEF}

Ine Fauzia

\section{EDITORIAL BOARD}

Sofyan al-Hakim, UIN Sunan Gunung Djati Bandung, Indonesia Deni Kamaludin Yusup, UIN Sunan Gunung Djati Bandung, Indonesia

Meria Utama, Fakultas Hukum Univrsitas Sriwijaya, Indonesia

Dewi Mayaningsih, UIN Sunan Gunung Djati Bandung, Indonesia

Andrey Sujatmiko, Fakultas Hukum Universitas Trisakti, Jakarta, Indonesia

Hetty Hassanah, Universitas Komputer Indonesia, Indonesia

Tarun Ghawana, CDMS, New Delhi, India

Muhammad Hasanuddin, UIN Sunan Gunung Djati Bandung, Indonesia

Syahrul Anwar, UIN Sunan Gunung Djati Bandung, Indonesia

Aden Rosadi, UIN Sunan Gunung Djati Bandung, Indonesia

\section{PEER-REVIEWERS}

S. Salahudin Suyurno, Universiti Teknologi MARA (UiTM) Melaka, Malaysia

Ezani Yaakub, Universiti Teknologi MARA (UiTM) Malaysia, Malaysia

Zezen Zaenal Mutaqin, University of California, Los Angeles, United States

Muhammad Irfan Helmy, IAIN Salatiga, Semarang, Indonesia

Ahmad Ali Nurdin, UIN Sunan Gunung Djati Bandung

Tajul Arifin, UIN Sunan Gunun Djati Bandung, Indonesia

Mohamad Anton Athoillah, UIN Sunan Gunung Djati Bandung, Indonesia

Renny Supriyatni, Universitas Padjadjaran, Indonesia

Ahmad Tholabi Karlie, UIN Syarif Hidayatullah Jakarta, Indonesia

Ija Suntana, UIN Sunan Gunung Djati Bandung, Indonesia

Ahmad Fathonih, UIN Sunan Gunung Djati Bandung, Indonesia

Fauzan Ali Rasyid, UIN Sunan Gunung Djati Bandung, Indonesia

Rahman Syamsuddin, Universitas Islam Negeri Alauddin Makassar, Indonesia

\section{PROOFREADER/DESIGN COVER}

Nanang Sungkawa

\section{LAYOUT EDITOR}

Opik Rozikin

Asy-Syari'ah has been accredited by The Ministry of Education and Cultere, Republic of Indonesia as an academic journal in Sinta 3 (SK Diirjen Penguatan Riset dan Pengembangan Kemristekdikti No. 14/E/KPT/2019), valid for 5 years from Volume 19 No. 1 Tahun 2017 until Volume 23 No. 2 Tahun 2022. 


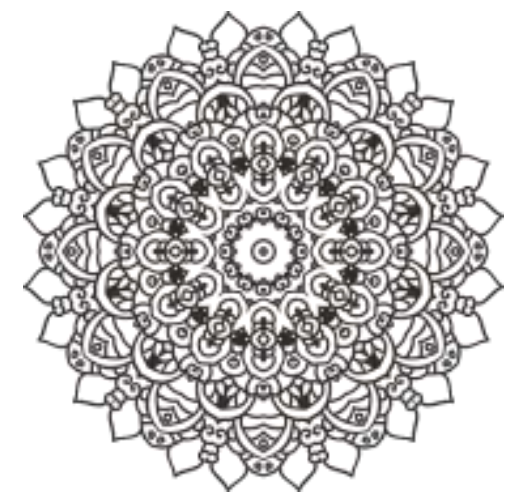

\title{
KEBIJAKAN FISKAL MASA AL-KHILAFAH AL-ISLAMIYAH
}

\author{
${ }^{1}$ Supriatna Supriatna, ${ }^{2}$ Dedah Jubaedah \\ ${ }^{1,2}$ Fakultas Syariah dan Hukum UIN Sunan Gunung Djati Bandung \\ E-mail: supriatna.aura@gmail.com, dedahjubaedah@uinsgd.co.id
}

\begin{abstract}
This article describes the policy of the Islamic fiscal management system managed by the state with the aim of improving the people welfare during the Khulafa arRasyidin era. This study uses a normative historical method and an exploratory approach that refers to various relevant literatures and is analyzed qualitatively. This research shows that the culture of the Islamic fiscal management system during the Khulafa ar-Rasyidin era tended to continue the Prophet's culture and development which included a balanced budget policy, as evidenced by the instruments of zakat, ghanimah, kharraj, jizyah, waqf, and others, and distributed for the welfare of society. The policy of managing the Islamic fiscal system is now widely used as a reference for developing a modern fiscal system. This result of this study found that the policy of the Prophet Muhammad regarding on fiscal management was continued by Khulafa ar-Rasyidin, which was a representation of the principles of public spending in the social, political, economics, and security context, whose it was based on the principle of a balanced budget policy. And then, the utilization of zakat, jizyah, kharaj, ghanimah, and waqf instruments as the sources of the state budget at this period, illustrating the dynamics of the caliph's fiscal policy progressively during the Khulafa ar-Rasyidin era, which was succeeded in bringing the Muslims to be in the golden age. Unfortunately, after the fall of the Abbasid Dynasty and continued to the colonialization period, Islamic fiscal policy was also declined.
\end{abstract}

Keywords: Islamic Economics; Islamic Fiscal Policy; Zakat; Taxes; Al-Khilafah Al-Islamiyah 
Abstrak: Artikel ini menjelaskan tentang kebijakan sistem pengaturan fiskal Islam yang dikelola oleh negara dengan tujuan untuk meningkatkan kesejahteraan masyarakat pada masa Khulafa ar-Rasyidin. Penelitian ini menggunakan metode historis normatif dan pendekatan eksploratif yang mengacu kepada berbagai literatur yang relevan dan dianalisis secara kualitatif. Penelitian ini menunjukan bahwa kebijaan sistem pengaturan fiskal Islam pada masa Khulafa ar-Rasyidin cenderung meneruskan kebiakan Rasulullah SAW berikut pengembangannya yang mencakup kebijakan anggaran berimbang, yang dibuktikan dengan instrumen zakat, ghanimah, kharraj, jizyah, wakaf, dan lainnya, serta didistribusikan untuk kesejahteraan masyarakat. Kebijakan pengelolaan sistem fiskal Islam tersebut kini banyak dijadikan rujukan untuk mengembangkan sistem fiskal modern. Penelitian ini menemukan bahwa kebijakan Rasulullah SAW mengenai pengelolaan fiskal yang kemudian dilanjutkan Khulafa ar-Rasyidin, merupakan representasi dari prinsipprinsip belanja publik dalam konteks sosial, politik, ekonomi, dan keamanan, yang manajemennya didasarkan pada prinsip kebijakan anggaran berimbang. Ada pun pendayagunaan instrumen zakat, jizyah, kharaj, ghanimah, wakaf sebagai sumber APBN pada masa itu, menggambarkan dinamika kebijakan fiskal khalifah setelah Khulafa arRasyidin bersifat progresif sehingga berhasil membawa umat Islam pada zaman keemasan. Namun setelah dinasti Abbasiyah runtuh diteruskan dengan kolonialisme kebijakan fiskal Islami mengalami deklinasi.

Kata-Kata kunci: Ekonomi Islam, Kebijakan Fiskal Islam; Zakat; Pajak; Al-Khilafah AlIslamiyah 


\section{Pendahuluan}

Kebijakan fiskal, dalam sudut pandang teori ekonomi konvensional, muncul sebagai dampak dari terjadi kegagalan mekanisme pasar (market failure). ${ }^{1}$ Lebih dari satu setengah abad lalu (tahun 1776-1936), para pakar ekonomi klasik yang hidup di era Adam Smith², kurang banyak memberi perhatian kepada sistem fiskal. ${ }^{3} \mathrm{Hal}$ ini dikarenakan keyakinan terhadap kemampuan pasar yang dapat dengan sendirinya mengatasi semua permasalahan ekonomi yang ada tanpa campur tangan pemerinah. ${ }^{4}$ Prinsip ini dikenal dengan leissez-faire (let it be)..$^{5}$ Akan tetapi, peristiwa Great Depression ${ }^{6}$ di USA tahun 1929-1932, telah menyentakan kesadaran mereka terhadap pentingnya kebijakan fiskal yang lebih bisa diandalkan dalam menciptakan pertumbuhan ekonomi yang baik dan stabil ${ }^{7}$, ketimbang mekanisme pasar bebas yang selama itu mereka anut.

John Maynard Keyness, yang banyak memberikan kritik terhadap keyakinan para ekonom klasik mempunyai pendapat senada terhadap pentingnya kebijakan fiskal, dan memberikan pandangan yang berbeda dengan para ekonom sebelumnya. ${ }^{8}$ Menurutnya, guna menciptakan kestabilan dan pertumbuhan ekonomi yang mantap, diperlukan intervensi pemerintah dalam bentuk kebijakan fiskal. ${ }^{9}$ Lebih lanjut, Keyness berpendapat, sejalan dengan aktivitas ekonomi yang semakin hari semakin beragam disertai dengan kompleksitas permasalahannya yang semakin tinggi, pengelolaan fiskal dengan disertai strategi yang tepat untuk mengarahkan sistem ekonomi sesuai kondisi yang diinginkan, tentunya sangat diperlukan. ${ }^{10}$

Namun demikian, dalam realisasinya, kebijakan fiskal yang telah ditetapkan oleh pemerintah tidak selalu bersesuaian dengan target yang diinginkan. Seringkali kebijakan tersebut terganggu oleh berbagai faktor di luar perkiraan, yang mengakibatkan timbulnya ketidakseimbangan pada anggaran. Kondisi ini juga diperkuat dengan pendapat beberapa

${ }^{1}$ Ali Murtadho, "Konsep Fiskal Islam dalam Perspektif Historis," Jurnal Economaca, vol. IV, no. 1, (2013): 33-50.

${ }^{2}$ Adam Smith, seorang ekonom klasik yang menawarkan prinsip pasar bebas dalam bukunya The Wealth of Nations, Vol. 1, (London: W. Strahan \& W. Cadell, 1776).

3 Kemenkeu, "Intervensi Pemerintah dalam Perekonomian: Bagian I Ringkasan Sejarah," Artikel DJKN, 2018, https://www.djkn.kemenkeu.go.id/artikel/baca/12670/Intervensi-Pemerintah-DalamPerekonomian-Bagian-I-Ringkasan-Sejarah.htm, diakses: 09/07/2020 16:03.

${ }^{4}$ Kemenkeu.

${ }^{5}$ Kemenkeu.

6 Peristiwa ini cukup menggoncangkan kondisi perekonomian Amerika, yang berdampak pada meroketnya tingkat pengangguran (seperempat dari tenaga kerja di Amerika menganggur), dan terjerembabnya pendapatan nasional Amerika.

${ }^{7}$ Kemenkeu, "Intervensi Pemerintah Dalam Perekonomian: Bagian I Ringkasan Sejarah."

8 Pandangan John Maynard Keyness ini selanjutnya menjadi landasan bagi teori makroekonomi modern. Pandangan tersebut terdapat dalam bukunya The General Theory of Employment, Interest, and Money, 2007 ${ }^{\text {th }}$ ed., (London: Pargrave Macmillan, 2007); Jessica Kuper; Adam Kuper, The Social Science Encyclopedia, $2^{\text {nd }}$ Ed., (New York: Routledge, 2001), 439-440; Sadono Sukirno, Makroekonomi Teori Pengantar, ed. 3, (Jakarta: RajaGrafindo Perkasa, 2010), 7.

${ }^{9}$ Sukirno, Makroekonomi Teori Pengantar, $7,85,184$.

${ }^{10}$ Sukirno, 7. 
pakar ekonomi yang menyatakan bahwa kebijakan fiskal, dilihat dari sisi penerimaan dan pengeluaran, adalah kebijaksanaan yang pada pelaksanaannya dapat membuat posisi anggaran menjadi seimbang, defisit, atau surplus. ${ }^{11}$

Melihat kenyataan yang ada, dalam kurun waktu 20 tahun terakhir, kesenjangan antara penduduk kaya dan miskin telah menjadi suatu hal yang menakutkan bagi para pimpinan negara di dunia ini. Bahkan saat ini, kurang lebih 85 orang terkaya diperkirakan memiliki jumlah uang setara dengan uang yang dimiliki oleh sekitar 3,5 miliar penduduk miskin di seluruh dunia. ${ }^{12}$ Kondisi ini menggambarkan dengan jelas implementasi sistem ekonomi kapitalis yang hanya berorientasi pada produksi dan pertumbuhan, minus pemerataan. ${ }^{13}$ Berbeda dengan sistem ekonomi Islam yang lebih berorientasi kepada pemerataan, atau distribusi yang lebih menjamin pada tercapainya pemenuhan kebutuhan publik secara seimbang dan adil ${ }^{14}$, yang bermuara pada kesejahteraan masyarakat. Demikian pula halnya dengan sistem fiskal Islam.

Kebijakan fiskal, dalam konsep ekonomi Islam, berbeda dengan kebijakan fiskal konvensional yang hanya memiliki target capaian dalam bentuk materi semata. Kebijakan fiskal Islam memiliki tujuan yang lebih luas lagi, yaitu mengembangkan suatu masyarakat berdasarkan pengaturan distribusi kekayaan yang berimbang. ${ }^{15}$ Tujuan tersebut juga disertai dengan penempatan nilai-nilai material dan spiritual pada tingkat yang sama ${ }^{16}$, sebagaimana diterapkan oleh Rasulullah SAW tatkala berhijrah ke, dan membangun negara, Madinah sekitar14 abad yang lalu. ${ }^{17}$

Secara historis, keberhasilan penerapan sistem fiskal Islam ${ }^{18}$ melalui pemberdayaan potensi zakat ${ }^{19}$, telah dibuktikan oleh Rasulullah SAW melalui keberhasilannya dalam membangun Madinah menjadi pusat negara yang memiliki kestabilan ekonomi. Pada saat itu, Rasulullah SAW telah berhasil membuat dan menerapkan kebijakan fiskal secara tepat, dengan mempertimbangkan berbagai faktor determinan ekonomi secara kontekstual. Selanjutnya, pada jaman ke-khalifah-an Umar bin Abdul Aziz, pajak telah dipertimbangkan keberadaannya sebagai salah satu instrumen yang melengkapi zakat ketika pemerintah melakukan langkah-langkah fiskal.

Namun, hubungan antara zakat dengan pajak menjadi terbalik seiring dengan berjalannya waktu. Sejak Islam mengalami kemunduran dan berada dalam cengkraman

\footnotetext{
${ }^{11}$ Novia Widya Utami, "Pengertian Kebijakan Fiskal dan Tujuannya", Jurnal Entrepreneur, 2020.

${ }^{12} \mathrm{CNN}$, "Global Economics Gap."

${ }^{13}$ Herza Ayu Menita, "Pemikiran Abdul Mannan tentang Ekonomi Islam," Jurnal Al-Intaj, vol. 3, no. 1, (2017): 216-238.

${ }^{14}$ Menita.

${ }^{15}$ Menita.

${ }^{16}$ Menita.

${ }^{17}$ Mustafa, "Sistem Ekonomi Keuangan Publik Berbasis Zakat," Jurnal Madani, vol 4, no. 1, (2014): 28-42.

${ }^{18}$ Tercantum dalam piagam Madinah.

${ }^{19}$ Mustafa, "Sistem Ekonomi Keuangan Publik Berbasis Zakat".
} 
hegemoni peradaban barat, hukum-hukum syara' dikesampingkan, sebaliknya hukum buatan manusia diutamakan. Tidak terkecuali zakat yang disubordinasikan dan diganti dengan kewajiban membayar pajak. ${ }^{20}$ Sebagai gambaran dari kebijakan fiskal yang didasari dengan kewajiban pajak bukan zakat, yang membuat umat muslim harus menanggung beban finansial ganda (pajak dan zakat) ${ }^{21}$, adalah pertanyaan yang sering muncul di kalangan umat Islam, yakni: "wajibkah muslim membayar pajak setelah dia membayar zakat atau sebaliknya?". Atas dasar itu, penulis melihat kebijakan fiskal Islam pada masa Khulafa al-Rasyidin merupakan salah satu obyek kajian yang masih menarik untuk dikaji.

\section{Metodologi}

Penelitian ini dilakukan dengan menggunakan metode deskriptif dan pendekatan kualitatif, yang mana pengumpulan data dilakukan melalui studi kepustakaan (library research) dan studi eksploratif. Data-data yang digunakan adalah data-data sekunder dari berbagai sumber yang terdapat dalam literatur terkait dengan penelusuran sejarah kebijakan fiskal pada masa Khulafa al-Rasyidin. Selain itu, juga merujuk kepada peraturan perundang-undangan dan/atau fatwa para Ulama, buku-buku, ensiklopedia, jurnal akademis, web page, proceeding, surat kabar, majalah, berita televisi, yang selanjutnya dianalisis secara deduktif dan induktif hingga penulis merumuskan kesimpulan tentang kebijakan dan pengelolaan fiskal Islam pada masa Khulafa al-Rasyidin.

\section{Kebijakan Fiskal Islam Masa Alkhilafah Al-Islamiyah}

Kebijakan fiskal (fiscal policy) atau sering disebut sebagai politik fiskal ${ }^{22}$ merupakan salah satu piranti kebijakan ekonomi makro ${ }^{23}$ yang berpengaruh pada tingkat aktivitas perekonomian. Kebijakan fiskal berfungsi sebagai perangkat manajemen keuangan negara untuk mengatur permintaan (demand management) melalui pengendalian pajak (taxation) ${ }^{24}$, pengeluaran pemerintah (government expenditure) ${ }^{25}$, mobilisasi sumber daya ${ }^{26}$, dan penentuan harga barang/jasa ${ }^{27}$, dengan tujuan mengatasi permasalahan ekonomi yang dihadapi. $^{28}$ Dengan demikian, langkah-langkah fiskal, di samping langkah-langkah

${ }^{20}$ Safarni Husain, "Zakat Penghasilan Sebagai Pengurang Penghasilan Kena Pajak," Jurnal Risalah 6, no. 1, (2010): 6-23.

${ }^{21}$ Husain.

22 Soediono Reksoprayitno, dalam Gampito, "Pemikiran Kebijakan Fiskal Ekonomi Islam," Jurnal JURIS 9, no. 1, (2010): 32-46.

${ }^{23}$ M. Faried M. Faried Wijaya, Ekonomikamakro, (Yogyakarta: BPFE, 2000), 5-7.

${ }^{24}$ Wikipedia, "Kebijakan Fiskal." diakses tanggal 01/04/2020 8:24

${ }^{25}$ Bryan Pass, Christopher; Lowes, Collins Dictionary of Economics, terj. Tumpal Rumapea \& Posman Haloho, "Kamus Lengkap Ekonomi," ed. 2, (Jakarta: Erlangga, 1994), 232.

${ }^{26}$ Wolfson, sebagaimana dikutip M. Suparmoko, Keuangan Negara dalam Teori dan Praktik, (Yogyakarta: BPFE-Yogyakarta, 1997), 257.

${ }^{27}$ Suparmoko.

${ }^{28}$ Sukirno, Makroekonomi Teori Pengantar, 184. 
moneter ${ }^{29}$, dipandang efektif untuk mengatasi problematika perekonomian, seperti laju inflasi yang tinggi dan berubah-ubah, menekan fluktuasi siklus bisnis, dan ikut berperan dalam menjaga pertumbuhan ekonomi serta penggunaan tenaga kerja yang tinggi. ${ }^{30}$ Langkah-langkah kebijakan fiskal yang diambil pemerintah bertujuan untuk mempengaruhi pengeluaran agregat (keseluruhan) ${ }^{31}$, agar tidak terjadi defisit pada APBN (Anggaran Pendapatan dan Belanja Negara) ${ }^{32}$ pada saat pemerintah membelanjakan pendapatannya untuk merealisasikan tujuan-tujuan ekonomi. ${ }^{33}$

Di dalam sistem fiskal ada dua jenis kebijakan yang dapat dipilih pemerintah, yaitu kebijakan ekspansif untuk merangsang kembali pertumbuhan ekonomi ${ }^{34}$, dan kebijakan kontraktif untuk menghambat laju pertumbuhan ekonomi dan menekan inflasi. ${ }^{35}$ Melalui stimulus fiskal, pendapatan masyarakat akan meningkat dan menghidupkan kembali fungsi konsumsi dan saving, yang pada akhirnya meningkatkan PDB (Produk Domestik Bruto). ${ }^{36}$ Dengan meningkatnya PDB, berarti penyerapan tenaga kerja bertambah dan tingkat pengangguran berkurang. ${ }^{37} \mathrm{Hal}$ ini sejalan dengan pandangan Ibnu Khaldun bahwa untuk menyeimbangkan perekonomian negara diperlukan intervensi pemerintah dalam bentuk penurunan pajak ${ }^{38}$ serta peningkatan pengeluaran (expenditure), atau sebaliknya. ${ }^{39}$

Ibnu Khaldun berpendapat, apabila pasar pemerintah (dalam hal pendapatan dan penerimaannya) mengalami penurunan, maka pasar yang lain pun akan mengikutinya, bahkan dalam agregat yang lebih besar. $4^{40}$ Arthur Laffer, penasihat ekonomi mantan Presiden Ronald Reagan, berterus terang bahwa ia menggunakan ide Ibnu Khaldun ketika menemukan teori Laffer's Curve. ${ }^{41}$ Demikian pula halnya, Abu Yusuf (731-798M), sebagaimana dikutip Adiwarman A. Karim, secara khusus menulis tentang kebijakan ekonomi

29 Kebijakan fiskal berbeda dengan kebijakan moneter, yang bertujuan untuk menstabilkan perekonomian dengan cara mengontrol tingkat bunga dan jumlah uang yang beredar.

${ }^{30}$ William D. Samuelson; Nordhaus, Makroekonomi, terj. Haris Munandar dari judul asli Economics, $4{ }^{\text {th }}$ ed., (Jakarta: Jakarta: Erlangga, 1997), 346.

${ }^{31}$ Sukirno, Makroekonomi Teori Pengantar, 25.

32 Tulus TH. Tambunan dalam Hendrawinata Eddy Siddharta, "Jelaskan kebijakan fiskal di Indonesia," Berita, 2015, http://www.fiskal.co.id/berita, diakses tanggal 30/03/2020 20:00.

33 Eko Suprayitno, Ekonomi Islam Pendekatan Ekonomi Makro Islam dan Konvensional, (Yogyakarta: Graha Ilmu, 2005), 159.

${ }^{34}$ Sugi Priharto, "Mengenal Lebih Jauh Kebijakan Fiskal," Artikel, 2020, https://accurate.id/ekonomikeuangan/pengertian-kebijakan-fiskal, diakses: 05/07/2020 23:28.

${ }^{35}$ Priharto.

${ }^{36}$ Wisynu Wardhana; Djoni Hartono, "Instrumen Stimulus Fiskal: Pilihan Kebijakan dan Pengaruhnya terhadap Perekonomian, Jurnal Ekonomi dan Pembangunan Indonesia, vol.12, no. 2, (2012): 107-15.

${ }^{37}$ Wardhana; Hartono.

${ }^{38}$ Pajak merupakan sumber utama pembelanjaan pemerintah.

${ }^{39}$ Ibn Khaldun, Muqaddimah, (Kairo, Mesir: Mathba'ah Musthafa Muhammad, n.d.), 286.

${ }^{40}$ Khaldun.

${ }^{41}$ Nima Sanandaji, "Why the Laffer Curve should really be called the 'Khaldun Curve,"' Artikel CAPX, 2018, https://capx.co/why-the-laffer-curve-should-really-be-called-the-khaldun-curve/, diakses: 18/07/2020 13:57. 
dalam kitabnya al-Kharraj ${ }^{42}$, yang menjelaskan mengenai tanggung jawab ekonomi pemerintah untuk memenuhi kebutuhan rakyatnya. ${ }^{43}$

Kebijakan fiskal memiliki tiga fungsi utama (trilogi fungsi fiskal), yaitu: (1) fungsi "alokasi anggaran" untuk tujuan pembangunan; (2) fungsi "distribusi dan subsidi" dalam upaya meningkatkan kesejahteraan rakyat; (3) dan fungsi "stabilisasi ekonomi" sebagai upaya meningkatkan pertumbuhan. ${ }^{44}$ Ketiganya mempunyai esensi pemerataan pembangunan, yang hasil-hasilnya diperuntukan bagi terciptanya kesejahteraan dan keadilan sosial, pertumbuhan ekonomi, serta terciptanya stabilitas nasional yang dinamis dan sehat. ${ }^{45}$ Oleh sebab itu, guna mempengaruhi sistem perekonomian menuju kondisi yang diinginkan, kewenangan pemerintah untuk campur tangan dalam pengelolaan fiskal sangat diperlukan. ${ }^{46}$ Kewenangan tersebut berupa hak deskresi untuk melakukan tindakan pengurangan dan/atau penambahan anggaran, baik di sisi penerimaan maupun di sisi pengeluaran. Tentu saja tindakan pemerintah tersebut dilakukan dengan mempertimbangkan faktor-faktor determinan ekonomi secara kontekstual ${ }^{47}$, karena tindakan fiskal yang dilakukan pemerintah dapat membuat posisi anggaran itu menjadi seimbang, defisit, atau surplus.

Secara konkrit kewenangan campur tangan pemerintah dalam kebijakan fiskal ${ }^{48}$ tercermin pada kebijaksanaan yang baru saja dikeluarkan Presiden Jokowi berupa penerbitan Perppu No. $1 / 2020^{49}$ dalam rangka perlindungan sosial dan stimulus ekonomi terkait dampak COVID-19..$^{50}$ Langkah-langkah luar biasa (extra ordinary) pemerintah yang tertuang dalam Perppu tersebut terkait dengan realokasi $\mathrm{APBN}^{51}$ dalam rangka

$4^{2}$ Al-Kharraj, kitab panduan tata keuangan negara pertama yang menjelaskan tentang hukum perpajakan dan cukai sebagai pedoman dalam menghimpun pemasukan negara yang berasal dari kharraj, 'usyr, dan jizyah di masa Khalifah Harus al-Rasyid. Muhammad Syamsudin, "Pemikiran Abu-Yusuf soal Ekonomi Negara dalam Kitab Al-Kharraj," Artikel Pustaka Beranda Islam Indonesia, 2019, https://www.nu.or.id/post/read/101873/pemikiran-abu-yusuf-soal-ekonomi-negara-dalam-kitab-al-kharaj, diakses: 16/07/2020 23:50.

${ }^{43}$ Adiwarman A. Karim, Ekonomi Islam suatu Kajian Kontemporer, (Jakarta: Gema Insani Press., 2001), 25 .

44 Supian; Mutirrahman Sauri, "Pajak Dan Zakat Ditinjau Dari Trilogi Fungsi Kebijakan Fiskal," in Seminar Nasional dan Call For Papers Ekonomi Syariah"Indonesia Sebagai Kiblat Ekonomi Syariah", (Malang: Perpustakaan UM, 2015), 252-263.

45 Sauri.

${ }^{46}$ Kemenkeu, "Intervensi Pemerintah Dalam Perekonomian: Bagian I Ringkasan Sejarah."

${ }^{47}$ Kemenkeu.

${ }^{48}$ Keyness, The General Theory of Employment, Interest, and Money; Mike Moffat, "The Government's Role in Economy," Article, 2017, sebagaimana dikutip Kemenkeu dalam Artikel DJKN, 2018.

${ }^{49}$ Kemenlu, "Kebijakan Pemerintah Republik Indonesia terkait Wabah Covid-19," Artikel Beranda, 2020, https://kemlu.go.id/brussels/id/news/6349/kebijakan-pemerintah-republik-indonesia-terkait-wabahcovid-19, diakses: 09/07/2020 17:36.

50 SCTV, "Liputan6 Sore", Berita, (Indonesia, 2020); Pingit Aria, "5 Point Penting dalam Perpu Kebijakan Ekonomi terkait Covid-19," Artikel katadata.co.id, 2020, https://katadata.co.id/ berita/ 2020/04/02/5-poin-penting-dalam-perpu-kebijakan-ekonomi-terkait-covid-19, diakses: 09/07/2020 16:59.

${ }^{11}$ Edward UP Nainggolan, "Kebijakan Fiskal dan Moneter menghadapi Dampak Covid-19," Artikel DKJN Kemenkeu, 2020, https://www.djkn.kemenkeu.go.id/artikel/baca/13017/Kebijakan-Fiskal-dan-MoneterMengadapi-Dampak-Covid-19.html, diakses: 14/07/2020 10:57. 
manyelamatkan stabilitas ekonomi nasional dan juga stabilitas moneter melalui kebijakan relaksasi (relaxation), serta memperkuat kewenangan berbagai lembaga dalam sektor keuangan. Langkah-langkah kebijakan fiskal yang luar biasa ini berupa instruksi tambahan belanja dan pembiayaan APBN 2020 sebesar 405,1 Triliun ${ }^{52}$, yang memungkinkan terjadinya defisit anggaran yang diperkirakan mencapai 5,07\%. ${ }^{53}$ Angka ini di atas batas maksimal defisit $3 \%{ }^{54}$ yang ditetapkan pemerintah sebagai disiplin defisit. Adapun faktorfaktor determinan yang menjadi pertimbangan pemerintah (illat) dalam mengubah kebijakan fiskal di sisi pengeluaran ini, adalah dampak sosial dan ekonomi sebagai akibat dari pademi Covid-19. ${ }^{55}$

Dalam teori ekonomi Islam, kebijakan fiskal antara lain bertujuan untuk menciptakan stabilitas ekonomi, meningkatkan pertumbuhan ekonomi, pemerataan pendapatan, serta mewujudkan keadilan dan kesejahteraan bagi masyarakat. ${ }^{56}$ Ditambah dengan tujuan lainnya yang terkandung dalam maqashid al-syariah. ${ }^{57}$ Sementara itu, Masudul Alam Choudhury dalam bukunya "Constributions to Islamic Economic Theory" sebagaimana dikutip Muslimin H. Kara ${ }^{58}$, mengatakan: bahwa prinsip ekonomi Islam adalah: (1) prinsip tauhid dan persaudaraan (the principle of tawheed and brotherhood), (2) prinsip kerja dan produktifitas (the principle of work and productivity), dan (3) prinsip pemerataan distribusi (the principle of distributional equity). Sementara itu, Adiwarman A. Karim ${ }^{59}$, berpendapat bahwa ekonomi Islam didasarkan atas lima nilai universal, yakni tawheed (tauhid), nubuwah (kenabian), adl (keadilan), khilafah (pemerintahan), dan ma'ad (hasil). Menurutnya, kelima nilai inilah yang mendasari penyusunan proposisi-proposisi serta teori-teori ekonomi Islam, termasuk di dalamnya tujuan kebijakan fiskal.

Selanjutnya, Abdul Manan ${ }^{60}$ berpendapat bahwa tujuan kebijakan fiskal dalam Islam adalah mengangkat status masyarakat yang didasarkan atas distribusi berimbang dengan menempatkan nilai-nilai material dan spiritual pada tingkatan yang sama. Sedangkan di sisi lain, Mustafa Edwin Nasution ${ }^{61}$, mengatakan bahwa di dalam ekonomi Islam kebijakan fiskal menempati posisi yang lebih penting dibandingkan kebijakan moneter. Larangan terhadap riba sebagaimana firman Allah Swt dalam OS. [2]: 276-278, OS. [3]: 130, OS. [4]:

${ }^{2}$ Aria, "5 Point Penting Dalam Perpu Kebijakan Ekonomi Terkait Covid-19"; Kemenlu, "Kebijakan Pemerintah Republik Indonesia Terkait Wabah Covid-19."

${ }^{53}$ Aria, "5 Point Penting Dalam Perpu Kebijakan Ekonomi Terkait Covid-19."

54 Aria.

55 Aria.

${ }^{56}$ Mustafa Edwin Nasution et. al., Pengenalan Ekslusif Ekonomi Islam, (Jakarta: Kencana Prenada Media Grup, 2007), 203.

57 Perlindungan terhadap keimanan (hifz al-din), kehidupan (hifz al-nafs), akal (hifz al-'aql), keturunan (hifz al-nasl), dan kekayaan (hifz al-mal). Lihat: Jasser Auda, Maqasid al-Shariah as Philosophy of Islamic Law: A System Approach, 1 st ed., (Herndon, USA: International Institute of Islamic Thought, 2008), 3.

${ }^{8}$ Muslimin H. Kara, Bank Syariah di Indonesia Analisis Terhadap Pemerintah Indonesia Terhadap Perbankan Syariah, (Yogyakarta: Universitas Islam Indonesia Press., 2005), 38.

${ }^{59}$ Adiwarman A. Karim, Ekonomi Makro Islami, (Jakarta: III T Indonesia, 2002), 17.

${ }^{60}$ M. Abdul Manan, Gampito, "Pemikiran Kebijakan Fiskal Ekonomi Islam."

${ }^{61}$ Nasution, Pengenalan Ekslusif Ekonomi Islam. 
161, QS. [30]:39, serta adanya kewajiban mengeluarkan zakat: ${ }^{62}$ OS. [2]: 43, OS. [2]: 83, OS. [6]: 141, OS. [31]: 4, OS. [9]: 58 dan 60, OS. [30]: 39, OS. [33]: 33, mengindikasikan sistem ekonomi Islam yang dilakukan oleh Rasulullah SAW pada tahun keempat hijrah hanya bersandar kepada kebijakan fiskal saja.

\section{Konsep Kebijakan dan Pengelolaan dalam Sistem Fiskal Islam}

Hasil penelitian menunjukan bahwa negara Islam yang dibangun oleh Rasulullah SAW tidak mewarisi harta sebagaimana layaknya dalam pendirian suatu negara. ${ }^{63}$ Saat awal negara Madinah didirikan, Rasulullah SAW hampir tidak menemukan sumber pemasukan dan pengeluaran negara. Pada waktu itu seluruh tugas dan kebutuhan negara dilaksanakan secara gotong royong. Penerimaan negara dipenuhi dari berbagai sumber yang tidak terikat. ${ }^{64}$ Ketika itu tidak ada tentara formal dengan gaji tetap. Setiap muslim yang mampu boleh menjadi tentara, dan berhak mendapat bagian dari ghanimah (rampasan perang). ${ }^{65}$

Guna memenuhi tanggung jawab negara dalam menyediakan anggaran yang memadai dalam mewujudkan kesejahteraan dan kemaslahatan warga, pemerintahan Rasulullah SAW memenuhi penerimaan negara yang berasal dari sumber-sumber, meliputi:

Pertama, Ghanimah. Rasulullah SAW mendapat bagian seperlima dari harta rampasan perang, dikenal dengan istilah khumus. Empat perlima lainnya dibagikan kepada pasukan yang terlibat dalam peperangan. ${ }^{66}$ Alokasi pembagian harta rampasan perang diatur sebagaimana dalam surah al-Anfaal yang turun setelah terjadi perang Badar pada tahun kedua hijrah. ${ }^{67}$ Pengenaan pajak 20\% (khumus) menggambarkan sistem pajak proporsional dalam sistem ekonomi Islam. Menurut Imam Abu Ubaid, yang dimaksud khumus bukan cuma hasil perang saja, tetapi juga barang tambang dan barang temuan lainnya, sebagaimana dikutip Adiwarman A. Karim. ${ }^{68}$

Kedua, Zakat. Pembayaran sedekah fitrah setiap bulan ramadhan diwajibkan sejak tahun kedua hijrah. Sedangkan, pembayaran zakat mal diwajibkan sejak tahun kesembilan hijrah. Pendapatan zakat dikumpulkan dan dikelola oleh pegawai yang mendapat bayaran dari dana zakat. ${ }^{69}$ Hasil penelitian menunjukan bahwa di awal masa Islam, zakat dikumpulkan dalam bentuk uang tunai dari usaha peternakan dan pertanian

${ }^{62}$ Tafsirweb, "Ayat Zakat," Artikel Tafsirweb, n.d., http://www.tafsirweb.com/38697-ayat-tentangzakat.html, diakses: 09/07/2020 19:25.

${ }^{6}$ Nasution, Pengenalan Ekslusif Ekonomi Islam.

${ }^{64}$ Adiwarman A. Karim, Sejarah Pemikiran Ekonomi Islam, ed. 3, (Jakarta: RajaGrafindo Persada, 2008), 37

${ }^{65}$ Munrokhim Misanam, et. al., Ekonomi Islam, (Jakarta: Rajawali Press., 2009), 489.

${ }^{66}$ Karim, Sejarah Pemikiran Ekonomi Islam.

${ }^{67}$ Karim.

${ }^{68}$ Karim, Ekonomi Makro Islami.

${ }^{69}$ Misanam, et. al., Ekon. Islam. 
bagi yang telah memenuhi nisab ${ }^{70}$. Jika kurang dari nisab, maka dibebaskan dari zakat. Pengenaan zakat peternakan dilakukan secara regresif (regressive rate) ${ }^{71}$, dan zakat pertanian dikenakan secara flat rate..$^{72}$ Oleh karena itu, penyaluran dana zakat diatur sesuai dengan ketentuan QS. [9]: 60, sehingga tidak dapat sembarangan dibelanjakan untuk keperluan umum negara. ${ }^{73}$

Ketiga, Kharaj. Kharaj adalah pengenaan pajak kepada penduduk Khaibar yang dikalahkan dalam perang di tahun ketujuh hijrah. Kepemilikan tanah diambil alih oleh orang muslim, sedangkan pemilik lamanya diijinkan Rasulullah mengolah tanah tersebut, dan memberikan sebagian hasilnya kepada negara, serta membayar kharaj dalam jumlah tertentu. ${ }^{74}$ Dalam perkembangannya, seperti diungkap Adiwarman A. karim, kharaj menjadi semacam pajak tanah seperti PBB (Pajak Bumi dan Bangunan). Perbedaannya dengan $\mathrm{PBB}$ adalah pemungutan kharaj ditentukan berdasarkan karakteristik tanah (kesuburan, jenis tanaman, dan jenis pengairannya) dan tingkat produktivitasnya, bukan berdasarkan penzonaan seperti halnya PBB. ${ }^{75}$

Ketiga, Jizyah. Jizyah, di masa Rasulullah, adalah pajak yang dikenakan kepada warga negara non-muslim (khususnya ahli kitab) ${ }^{76}$ yang mampu, sebagai jaminan perlindungan jiwa dan properti yang mereka miliki. ${ }^{77}$ Sementara itu, manula, anak-anak, perempuan, pendeta, pengemis, dan bagi penderita gangguan jiwa serta bagi semua yang menderita penyakit, dibebaskan dari pungutan jizyah. Jizyah dibayarkan tidak harus dalam bentuk uang tunai, tetapi dapat berupa barang atau jasa. ${ }^{7}$ Ketika terjadi krisis dalam perekonomian yang berdampak pada kemiskinan, maka pembebanan jizyah kepada warga negara yang jatuh miskin dihapuskan. Sebaliknya, negara menyantuni mereka yang dananya diambil dari orang-orang kaya. ${ }^{79}$ Di masa sekarang, tindakan seperti ini disebut kebijakan fiskal ekspansif, yang dilakukan pemerintah ketika terjadi resesi, dengan cara menambah belanja pemerintah (government expenditures) dan atau menurunkan pajak (taxes).

Keempat, Sumber Pendapatan lainnya. Selain sumber-sumber penerimaan di atas, terdapat pendapatan lain yang bersumber dari kaffarah (denda) yang dikenakan kepada, misalnya suami istri yang berhubungan di siang hari di bulan ramadhan. ${ }^{80}$ Demikian pula

\footnotetext{
${ }^{70}$ Nisab untuk dinar dan dirham masing-masing 20 dinar dan 200 dirham, dan zakat yang dikeluarkan sebesar 2,5\% dari jumlah nisab. Lihat Adiwarman A. Karim, Ekonomi Makro Islami.

${ }^{71}$ Semakin banyak jumlah hewan peliharaan, semakin kecil rate-nya dan ada pembedaan pada ukuran untuk tiap jenis hewan.

${ }_{72}$ Dibedakan antara jenis pengairannya.

${ }^{73}$ Misanam, et. al., Ekon. Islam.

${ }^{74}$ Misanam, et. al.

${ }^{75}$ Karim, Ekonomi Makro Islami.

${ }^{76}$ Karim, Sejarah Pemikiran Ekonomi Islam.

${ }_{77}^{73}$ Misanam, et. al., Ekon. Islam.

${ }^{78}$ Karim, Sejarah Pemikiran Ekonomi Islam.

${ }^{79}$ Nasution, Pengenalan Ekslusif Ekonomi Islam.

${ }^{80}$ Lilik Rahmawati, "Sistem Kebijakan Fiskal Modern dan Islam," OECONOMICUS Journal of Economics, vol. 1, no. 1, (2016): 21-48.
} 
halnya dengan orang muslim yang meninggalkan negerinya ${ }^{81}$ dan orang muslim meninggal yang sama sekali tidak mempunyai ahli waris ${ }^{82}$, maka hartanya atau warisannya akan dimasukan ke lembaga baitul mal ${ }^{83}$ sebagai pendapatan negara. ${ }^{84}$ Pada masa sekarang, hal tersebut juga dipertegas dengan KHI (Kompilasi Hukum Islam) Pasal $191 .^{85}$ Pendapatan atas denda dan lainnya disetorkan ke kas negara (baitul mal).

Seiring dengan berjalannya waktu, wakaf menjadi salah satu sumber pendapatan yang penting dalam pemerintahan Islam. ${ }^{86}$ Wakaf dalam pandangan hukum syara' adalah menahan harta yang mungkin diambil manfaatnya. Hal ini memberi pengertian bahwa properti yang di-wakaf-kan dilarang untuk dijual atau diserahterimakan kepada orang lain atau dihabiskan. Tanah sebagai objek wakaf telah memainkan peran yang penting dalam pemerintahan Islam. ${ }^{87}$ Seperti di Dinasti Turki Ustmani, $75 \%$ lahan yang ditanami adalah tanah wakaf.

Selanjutnya, di Mesir pada tahun 1949, sekitar seperdelapan lahat pertanian adalah tanah wakaf. Demikian pula halnya di Tunisia di abad 19, sepertiga tanahnya adalah tanah wakaf. Di Iran pada tahun 1930, 30\% lahan pertaniannya adalah tanah wakaf. Sedangkan di Aljazair pada masa penjajahan Perancis pertengahan abad 19, kira-kira separuh tanah yang ada adalah tanah wakaf. Wakaf dapat ditunaikan dengan harta bergerak atau tidak bergerak. Kalangan Malikiyyah membolehkan memberikan wakaf dalam bentuk asset apapun termasuk dalam bentuk uang tunai ${ }^{88}$, sedangkan menurut kalangan Safi'iyyah, wakaf tunai tidak sah. ${ }^{89}$ Di Indonesia, Wakaf dalam bentuk uang tunai dibolehkan menurut peraturan yang dituangkan dalam Fatwa Majelis Ulama Indonesia (MUI) Nomor 2 Tahun 2002 tentang Wakaf Uang.

Sejalan dengan bertambah kuatnya kedaulatan negara Islam di seluruh jazirah Arab, pendapatan negara pun semakin meningkat. Pasca pendudukan Makkah, negara Islam mengumumkan status dan posisinya dengan menawarkan ketertiban umum kepada seluruh pembesar-pembesar kabilah Arab. Banyak delegasi kabilah bangsa Arab, antara lain: Bani Abdu Qais, Tamim, Bani Hanifah, Thaiy, al-Azd, Hamdan, Tajib, Bani Tsa'labah,

${ }^{81}$ Sairi Erfanie, Kebijakan Anggaran Pemerintah, (Yogyakarta: Kreasi Wahana, 2005), 145.

${ }^{82}$ Erfanie.

${ }^{83}$ Oemar Moechthar, "Kedudukan Negara Sebagai Pengelola Warisan Atas Harta Peninggalan Tak Terurus Menurut Sistem Waris Burgerlijk Wetboek," Jurnal Yuridika FH Unair, vol. 32, no. 2, (2017): 280-309.

${ }^{84}$ Karim, Ekonomi Makro Islami; Rahmawati, "Sistem Kebijakan Fiskal Modern Dan Islam."

${ }^{85}$ KHI Buku 2, Pasal 191: Apabila pewaris tidak meninggalkan ahli waris sama sekali, atau ahli warisnya tidak diketahui ada tidaknya, maka harta tersebut atas putusan pengadilan agama diserahkan kepengurusannya kepada baitul mal untuk kepentingan agama Islam dan kesejahteraan umum.

${ }^{86}$ Muhammad Saddam, Ekonomi Islam, (Jakarta: Gramedia, 2002), 89.

${ }^{87}$ Ratna Dewi Sofiani, "Wakaf Tunai: Instrumen Alternatif Kemakmuran Umat", Makalah FE UI, (Depok, 2003).

${ }^{88}$ Rahmawati, "Sistem Kebijakan Fiskal Modern Dan Islam."

${ }^{89}$ Mustafa Kamal, "Wakaf Tunai Menurut Pandangan Fiqh Syāfilyah Dan Fatwa Majelis Ulama Indonesia No.2 Tahun 2002 Tentang Wakaf Uang," Jurnal Ilmiah Islam Futura, vol. 15, no. 1, (2015): 93-110, https://doi.org/10.22373/jiif.v15i1.560. 
Bani Sa'ad Hudaim, dan lain-lain ${ }^{90}$, menyatakan loyalitasnya dan bergabung dengan negara Islam. Dengan bergabungnya para kabilah ini, potensi ekonomi negara Islam semakin diperkuat, dan distribusi kekayaan di antara mereka diberikan secara adil dan merata. Dengan demikian, Rasulullah SAW sebagai pemimpin telah meletakkan landasan kebijakan fiskal yang berbasis keadilan, dan menjamin bagi terpenuhinya kebutuhan manusia secara utuh, baik kebutuhan yang bersifat jasmaniah maupun kebutuhan naluriah (spiritual dan aktualisasi diri). ${ }^{91}$

Di samping sumber pemasukan negara di atas, Rasulullah SAW juga menjadikan harta milik umum (sumber daya alam) ${ }^{92}$ sebagai barang yang harus dikelola negara, dan hasilnya diperuntukkan bagi pembangunan infrastruktur demi kemaslahatan bersama, sebagaimana dinyatakan dalam hadist ${ }^{93}$ yang diriwayatkan Imam Abu Dawud dari Abyadl bin Hamal al-Mazaniy ${ }^{94}$.

Kebijakan membagikan harta rampasan perang ini, menurut beberapa pemikir sebelumnya dipandang telah mendorong peningkatan pendapatan, yang pada akhirnya meningkatkan permintaan agregatif (aggregative demand). Ada pun kebijakan pemungutan pajak atas setiap jenis usaha, berhasil mengurangi inflasi serta menciptakan kestabilan harga. Dalam kondisi stagnasi karena menurunnya permintaan agregatif (aggregative demand) dan penawaran agregatif (aggregative supply), kebijakan pajak (khususnya khums) mendorong stabilitas pendapatan dan produksi total. Kebijakan ini tidak mengakibatkan penurunan harga maupun jumlah produksi. ${ }^{95}$

Berdasarkan hasil penelitian, lembaga baitul mal (house of money) yang berkedudukan di masjid didirikan Rasulullah SAW sesaat setelah hijrah. ${ }^{96}$ Lembaga ini dibentuk untuk menghimpunan kekayaan negara sekaligus menertibkan anggaran pendapatan dan belanja negara, di mana pengaturan penggunaannya dilakukan secara fleksibel. Dana yang terhimpun di dalam baitul mal tidak ada yang tidak didistribusikan. Pengelolaan baitul mal berlanjut pada masa Abu Bakar tanpa adanya perubahan. Perubahan pada sistem

90 Muh. Rawwas Qol'ahji, Sirah Nabawiyah Sisi Politis Perjuangan Rasulullah Saw, terj. Tim al-Izzah dari judul asli Sirah Nabawiyah, (Bogor: Al-Azhar Press., 2013), 443.

${ }^{91}$ Kunaifi, "Telaah Kritis Kebijakan Fiskal."

92 Lulu Killiyah, "Sumber Pendapatan Ekonomi Masa Rasulullah," Artikel Hima Prodi ESY STAIS, 2018, https://www.himaprodiesystais.wordpress.com/sumber-pendapatan-ekonomi-masa-rasulullah, diakses: $09 / 07 / 202022: 13$.

93 yang berbunyi: "Sesungguhnya dia mendatangi Rasulullah Saw, dan meminta beliau Saw agar memberikan tambang garam kepadanya. Ibnu Mutawakkil berkata: Yakni tambang garam yang ada di daerah Ma'rib. Nabi pun memberikan tambang itu kepadanya. Ketika dia (Abyadl bin Hamal) telah pergi, seorang lakilaki yang ada di majelis itu berkata: Tahukah Anda apa yang telah Anda berikan kepadanya? Sesungguhnya Anda telah memberikan kepadanya sesuatu yang seperti air mengalir. Ibnu Mutawakkil berkata: Lalu Rasulullah Saw mencabut kembali pemberian tambang garam itu darinya".

${ }^{94}$ Fathiy Syamsuddin Ramadhan An-Nawy, Panduan Lurus Mamahami Khilafah Islamiyyah manurut Kitab Kuning, (Jakarta: Wadi Press., 2013), 389-390.

${ }^{95}$ Karim, Ekonomi Makro Islami.

${ }^{96}$ Munte, "Sejarah Baitul Mal Pada Masa Awal Islam." 
administrasi pengelolaan baitul mal baru terjadi pada masa Umar bin Khattab ${ }^{97}$, yang memberi pemahaman bahwa pengelolaan keuangan negara merupakan amanat publik, yang harus dikelola sebaik mungkin, dengan prosedur yang paling praktis dan efektif.

Rasulullah SAW dalam mengelola keuangan negara menganut prinsip kebijakan anggaran berimbang (balance budget policy), di mana semua penerimaan dihabiskan untuk pengeluaran negara. Kebijakan ini membuat anggaran senantiasa berada pada posisi equilibrium. ${ }^{98}$ Artinya, berapapun penerimaan yang masuk, disimpan di masjid, dan dalam waktu singkat didistribusikan kepada masyarakat tanpa tersisa. ${ }^{99}$ Rasulullah SAW tidak suka menerapkan kebijakan defisit anggaran (budget deficit policy). Dengan demikian, pada masa Rasulullah SAW, pengeluaran hanya boleh dilakukan apabila ada penerimaan. Hal yang sama juga terdapat dalam ajaran yang terkandung dalam kitab Mahabharata ${ }^{100}$, yang menyatakan bahwa "penguasa berhak mengumpulkan uang, membangun bendahara yang kuat, dan vang tersebut harus digunakan sebanyak-banyaknya untuk menolong rakyat" . ${ }^{01}$

Namun demikian, hasil penelitian menunjukan, bahwa Rasulullah SAW di masanya hanya satu kali pernah mengalami defisit anggaran, yaitu pada saat fathul Mekkah. ${ }^{102}$ Saat itu banyak orang masuk Islam (mu'allaf), yang mengakibatkan pengeluaran baitul mal lebih besar dari penerimaannya. Tetapi, defisit (fuqara') ini segera dilunasi setelah usai perang Hunain. ${ }^{103}$ Malah di jaman Umar bin Khattab dan Utsman bin Affan, anggaran mengalami surplus, yang memberi dampak tidak adanya uang baru dicetak. Dalam kondisi ini inflasi yang disebabkan ekspansi moneter tidak akan terjadi. ${ }^{104}$ Ada pun inflasi yang pernah terjadi di masa Rasulullah SAW dan Khulafa ar-Rasyidin lebih disebabkan oleh terbatasnya pasokan barang pada waktu musim paceklik atau ketika perang. ${ }^{105}$

Pada masa Rasulullah SAW dan Khulafa ar-Rasyidin, pengeluaran pemerintah (goverment expenditure) di samping untuk biaya pertahanan dan administrasi, lebih berorientasi pada kesejahteraan sosial. Pengeluaran tersebut juga ditujukan untuk memberi tunjangan bagi orang miskin, bantuan bagi penuntut ilmu, membebaskan budak, membayar utang bagi orang yang meninggal dalam kemiskinan, membayar denda atas

${ }^{97}$ Kadim As-Sadr, "Kebijakan Fiskal pada Awal Pemerintahan Islam," dalam Adiwarman A. Karim, Sejarah Pemikiran Ekonomi Islam.

${ }^{98}$ Mohamad Hidayat, Pengantar Ekonomi Islam, (Jakarta: Pusat Komunikasi Ekonomi Syariah, 2009), 116.

${ }^{99}$ M.A. Sabzwari, dalam Adiwarman A. Karim, Sejarah Pemikiran Ekonomi Islam.

${ }^{100}$ Mahabharata adalah salah satu kitab suci India kuno disamping Manu Smriti, Arthasastra, dan Shukranti.

${ }^{101}$ B. Lal Sharma, Economic Ideas in Ancient India before Kautilya, (New Delhi: Ramchand Vidya Bhawan, 1987), 12.

${ }^{102}$ Rahmawati, "Sistem Kebijakan Fiskal Modern Dan Islam."

${ }^{103}$ Rahmawati,

${ }^{104}$ Novirin, Ekonomi Moneter, Buku 1, (Yogyakarta: BPFE Yogyakarta, 1993), 45

${ }^{105}$ Karim, Ekonomi Makro Islami. 
mereka yang secara tidak sengaja terbunuh oleh pasukan muslimin, bantuan bagi musafir, dan juga untuk cadangan darurat. ${ }^{106}$

Kebijakan fiskal yang diterapkan pada era permulaan Islam memberikan dampak positif terhadap tingkat investasi, penawaran agregat, dan secara tidak langsung berdampak pada tingkat inflasi dan pertumbuhan ekonomi. ${ }^{107} \mathrm{Hal}$ ini tercermin pada kebijakan pertama Rasulullah SAW setelah hijrah, menyediakan lapangan pekerjaan bagi Muhajirin sekaligus meningkatkan pendapatan nasional muslim dengan menerapkan kontrak-kontrak muzara, musaqat, dan mudharabah. Di samping itu Rasulullah SAW menyediakan lapangan kerja dalam bentuk kerja sama terbatas antara kelompok Muhajirin (yang menyediakan tenaga kerja) dengan kelompok Anshar (yang memiliki lahan pertanian, perkebunan, dan kekayaan). ${ }^{108}$

Penguatan ikatan persaudaraan antara Muhajirin dengan Anshar yang dilakukan Rasulullah menghasilkan peningkatan permintaan agregat masyarakat muslim di Madinah. ${ }^{109}$ Kebijakan Rasulullah SAW ini mengakibatkan terjadinya distribusi pendapatan dari kaum Anshar kepada kaum Muhajirin. ${ }^{110}$ Distribusi pendapatan ini akan meningkatkan permintaan total di Madinah karena kelompok Muhajirin memiliki kecenderungan konsumsi yang lebih besar dari pada orang-orang Anshar. ${ }^{111}$ Demikianlah dasar-dasar kebijakan sistem fiskal Islam, yang telah dibangun Rasulullah SAW sejak awal pemerintahan Islam.

Pasca wafatnya Rasulullah SAW, kebijakan ini kemudian dilanjutkan oleh generasi penerusnya, bahkan dikembangkan dengan mempertimbangkan faktor-faktor determinan ekonomi yang ada di jamannya. Seperti pada jaman kekhalifahan Abu Bakar As-Shiddiq (11-13H/632-634M), pengelolaan zakat ditata lebih profesional, mengakurasi perhitungannya, sehingga menghasilkan pendapatan yang optimal bagi kas negara (baitul mal). ${ }^{112}$ Pada masa ini lembaga baitul mal dikembangkan dengan menerapkan konsep balance budget policy dengan mendistribusikan seluruh pendapatan tanpa tersisa ${ }^{113}$, dan mengangkat penanggung jawab baitul mal. Upaya optimalisasi zakat dan redistribusi yang adil, pada saat itu, merupakan kebijakan fiskal yang mampu memberikan kesejahteraan lebih meluas

${ }^{106}$ Hidayat, Pengantar Ekonomi Islam, 116.

${ }^{107}$ Karim, Ekonomi Makro Islami.

${ }^{108}$ Mohammad Suyanto, "Kebijakan Fiskal pada Masa Rasulullah S.A.W. (1)," Jurnal Universitas Amikom Yogyakarta, 2006, https://journal.amikom.ac.id/index.php/Koma/article/view/1298, diakses: 20/07/2020 17:23.

${ }^{109}$ Suyanto.

110 Suyanto.

${ }^{111}$ Suyanto.

${ }^{112}$ Ahmad Musyaddad, "Kebijakan Fiskal di Masa Pemerintahan Abu Bakar Ash-Shiddiq," Jurnal Ekonomi Islam Al-Infaq, vol. 4, no. 2, (2013): 212-227.

113 Hamdani MA., "Sistem Fiskal Dan Inflasi Pada Masa Abu Bakar As-Shiddiq AS," Jurnal Ekonomi Bisnis Sosial INVESTAMA, vol. 3, no. 1, (2009): 73-83, https://ejournal.iaingawi.ac.id/index.php/ investama /article/view/380/o. 
kepada seluruh warga negara Islam, sehingga kesenjangan dapat diminimalisir. ${ }^{114}$ Selain itu, penegakan hukum dilakukan secara tegas bagi pihak yang tidak mau membayar zakat, dan memerangi kelompok murtad dan pembangkang dengan sebutan perang Riddah. ${ }^{115}$

Pada masa Umar bin Khattab (13-23H/634-644M), wilayah ke-khilafah-an semakin berkembang dan sistem administrasi khilafah semakin rapi. Kebijakan fiskal yang diterapkan ketika itu antara lain menjadikan baitul mal sebagai lembaga permanen, mendirikan cabang-cabang baitul mal di setiap provinsi, membagi pos belanja ke dalam beberapa departemen seperti hukum, militer, investasi, pendidikan, dan jaminan sosial. ${ }^{116}$ Selain itu, melalui kebijakan fiskal dibangun berbagai fasilitas umum dan infrastruktur, seperti membangun perkotaan di daerah Mousul, Mesir, Kufah, Syam, Bashrah, serta membangun sarana transportasi laut dari Mesir ke Madinah. ${ }^{117}$ Rumah tepung (sejenis bulog) untuk menyimpan dan mendistribusikan bahan-bahan pokok (seperti gandum, kismis, dan lainnya) juga dibangun khalifah Umar, untuk kemudian dikonsumsi secara cuma-cuma bagi yang membutuhkan (musafir). ${ }^{118}$

Selanjutnya, khalifah Utsman bin Affan, disamping terus melanjutkan kebijakan fiskal khalifah sebelumnya, juga melakukan stimulus pada produksi pertanian dan sumber daya alam lainnya dengan membangun saluran pengairan (irigasi), melakukan pembangunan jalan, memperkuat sistem keamanan (kepolisisan), serta meningkatkan kekuatan armada laut dan pembangunan pelabuhan. ${ }^{119}$ Khalifah Utsman juga berupaya agar lahan-lahan semakin produktif dengan memberikan keleluasaan hak kelola bagi individu yang sanggup. Selain itu, ladang penggembalaan juga dibangun untuk meningkatkan produksi di sektor peternakan. ${ }^{120}$ Sedangkan, di masa ke-khalifah-an Ali bin Abi Thalib, kebijakan dan pengelolaan fiskal lebih diarahkan pada target memperkuat sumber pemasukan baitul mal dengan sedikit perubahan pada sistem pendistribusiannya. Selain itu, demi menjamin transaksi yang fair, Imam Ali membuat regulasi kontrol pasar dengan menempatkan pengawas pasar untuk memberantas pedagang yang licik, penimbun barang, dan pasar gelap. ${ }^{121}$ Pada saat itu sektor pertanian terus digairahkan dan melarang pemungutan kharaj (pemungutan hasil pertanian) sebelum hasil produksinya membaik. ${ }^{122}$

Pasca Khulafa ar-Rasyidin, ke-khalifah-an diteruskan oleh Bani Ummayah (41132H/661-749M). Daulah Umayyah telah menunjukkan keberhasilannya dalam usaha

${ }^{114}$ Ika Yunia Fauzia, Etika Bisnis dalam Islam, (Jakarta: Kencana Prenata Media Grup, 2013), 45.

${ }^{115}$ Sabzwari, "Economic and Fiscal System during Khulafa ar-Rasyidin," Jurnal Banking Karachi, vol. 2, (n.d.), 6.

${ }^{116}$ Fauzia, Etika Bisnis Dalam Islam.

${ }^{117}$ Euis Amalia, Sejarah Pemikiran Ekonomi Islam dari Masa Klasik hingga Kontemporer, (Jakarta: Gramata Publishing, 2010).

${ }^{118}$ As-Suyuthi, Tarikh Al-Khulafa', Terj, Samson Rahman Dari Judul Asli Tarikh Al-Khulafa', 86-87.

${ }^{119}$ Fauzia, Etika Bisnis Dalam Islam.

${ }^{120}$ As-Suyuthi, Tarikh al-Khulafa', 191.

${ }^{121}$ Amalia, Sejarah Pemikiran Ekonomi Islam dari Masa Klasik hingga Kontemporer.

${ }^{122}$ Fauzia, Etika Bisnis Dalam Islam. 
membangun perekonomian dan menetapkan kebijakan fiskal yang tepat pada masa pemerintahan 'Umar ibn 'Abd al-'Aziz (99-101H/717-719H) ${ }^{123}$ khalifah ke-8 dinasti keluarga Ummayah. ${ }^{124} \mathrm{Di}$ tangannya pengelolaan zakat mengalami reformasi dan hasilnya menjadi sangat memukau, sehingga zakat pada masa itu mencapai puncak kegemilangannya sebagai instrumen utama sistem fiskal. ${ }^{125}$ Diversifikasi dalam pemungutan zakat, membuat dana zakat menjadi berlimpah ruah di baitul mal. ${ }^{126}$ Kekuatan zakat, infaq, sadaqah, dan wakaf sebagai solusi untuk mengentaskan kemiskinan benar-benar dioptimalkan pengumpulannya di masa itu. Hal ini terbukti, hanya dalam waktu 2 tahun 6 bulan, dengan pengelolaan sistem yang profesional, koprehensif, dan universal, membuat negara menjadi makmur bebas dari orang miskin. ${ }^{127}$ Bahkan, saat itu, amil zakat sulit sekali menemukan fakir miskin yang membutuhkan dana zakat. ${ }^{128}$ Kondisi tersebut tentu saja berdampak pada peningkatan stabilitas sosial dan politik, serta keamanan kaum muslimin.

Era ke-khalifah-an Bani Abbasiyah (132-656H/794-1200M) adalah puncak produktivitas ilmu pengetahuan. ${ }^{129}$ Di masa itu berdiri bait al-hikmah (house of wisdom) yang berfungsi sebagai perpustakaan sekaligus sebagai universitas yang bukan cuma berpengaruh pada perkembangan ilmu pengetahuan di dunia Islam, tetapi juga memberi angin segar bagi masyarakat Eropa Barat. ${ }^{130}$ Model pembiayaan untuk program-program pembangunan diperoleh pemerintah dari pendapatan yang bersumber pada zakat, kharaz, dan jizyah. ${ }^{131}$ Saat itu pemerintahan Abbasiyah menerapkan kebijakan ekonomi dengan melakukan diversifikasi sumber pemasukan negara, sehingga mencapai kegemilangan di hampir semua bidang, baik di bidang politik, ekonomi, ilmu pengetahuan, militer, dan peradaban Islam. ${ }^{132}$ Hal ini dibuktikan dengan perkembangan riset dalam ilmu pengetahuan, yang secara gemilang mendorong tercapainya persatuan, keamanan, kecerdasan, dan kesejahteraan masyarakat di masa itu. ${ }^{133}$ Daulah Abbasiyah mencapai puncak kemakmurannya ketika tampuk pemerintahan dikuasai khalifah Harun al-Rasyid. Bahkan di akhir masa pemerintahan Harun al-Rasyid, kebijakan fiskal yang diterapkannya membukukan

${ }^{123}$ Ruslan Husein Marasabessy, "Analisasi Pola Distribusi Zakat pada Masa Daulah Umayyah dan Abbasiyah," Jurnal Asy- Syukriyyah, vol. 18, (2017): 132-150.

${ }^{124}$ Syahruddin El-Fikri, "Cara Dinasti Ummayah dan Abbasiyah Menerapkan Pajak," Artikel Khazanah, 2017, https://khazanah.republika.co.id/berita/dunia-islam/islam-digest/17/03/16/omwywf313-caradinasti-umayyah-dan-abbasiyah-menerapkan-pajak, diakses: 14/07/2020 10:21.

${ }^{125}$ Marasabessy, "Analisasi Pola Distribusi Zakat pada Masa Daulah Umayyah dan Abbasiyah," 136137.

${ }^{126}$ Marasabessy.

${ }^{127}$ Marasabessy.

${ }^{128}$ Marasabessy.

129 Nilawati Tadjuddin; Alif Maulana, "Kebijakan Pendidikan Khalifah Harun Ar-Rasyid," AlTadzkiyyah: Jurnal Pendidikan Islam, vol. 9, no. 2, (2018): 325-346, https://doi.org/10.24042/atjpi.vgi2.3633.

${ }^{130}$ Suwito, Sejarah Sosial Pendidikan Islam, (Jakarta: Kencana Prenada Media Grup, 2015).

${ }^{131}$ Marasabessy, "Analisasi Pola Distribusi Zakat Pada Masa Daulah Umayyah Dan Abbasiyah."

${ }^{132}$ Marasabessy.

${ }^{133}$ Tadjuddin and Maulana, "Kebijakan Pendidikan Khalifah Harun Ar-Rasyid." 
surplus APBN sebesar 900.000.000 dinar. ${ }^{134}$ Jumlah ini merupakan suatu jumlah yang tidak sedikit pada masa itu.

Terakhir tapi bukan yang penghabisan, khilafah Ustmaniyah (1300-1924M) adalah negara modern yang telah memiliki sistem administrasi dan tata kelola pemerintahan yang rapi, pembangunan industri pertanian, perdagangan, dan militer. ${ }^{135}$ Terlebih lagi, pada masa pemerintahan Sultan Sulaiman al-Qanuni (1520-1566M) yang bergelar "Solomon The Magnificent ${ }^{\prime \prime 36}$, kerajaan Islam Ustmani telah menjelma menjadi negara adikuasa yang disegani dalam bidang politik, ekonomi, dan kekuatan militer yang sangat tangguh. ${ }^{137}$ Pada masa itu berkembang berbagai pemikiran-pemikiran ekonomi yang mewarnai kebijakan pemerintah, termasuk kebijakan fiskal. Realisasi kebijakan fiskal pemerintahan Turki Ustmani pada saat itu sangat memprioritaskan pelayanan terhadap masyarakat seperti pembangunan fasilitas umum, antara lain: memperindah ibu kota serta kota-kota lain, membangun mesjid, sekolah, rumah sakit, jembatan, terowongan, jalur kereta, dan pemandian umum, serta sarana-sarana penunjang aktivitas rakyat. ${ }^{138}$ Ada pun, penerimaan negara diperoleh dari pendapatan yang berasal dari perdagangan, hasil pajak, zakat, harta wakaf, dan aktivitas ekonomi lainnya. ${ }^{139}$

Demikian kesuksesan perkonomian masyarakat selama masa diberlakukannya syariah secara kaffah dalam sebuah institusi negara. Hal ini dikuatkan dengan pendapat Imam al-Ghazali yang menegaskan: "tujuan utama syariat (maqashid) adalah mendorong manusia untuk mencapai kesejahteraan yang bertumpu pada perlindungan keimanan (hifz al-din), kehidupan (hifz al-nafs), akal (hifz al-'aql), keturunan (hifz al-nasl), dan kekayaan (hifz al-mal) mereka. Apa pun yang menjamin terlindungnya dan terpeliharanya lima perkara ini, maka akan memenuhi kepentingan umum dan dikehendaki". ${ }^{140}$ Hasil penelitian menunjukan bahwa perekonomian negara, di masa kekuasaan Islam, telah menciptakan kemakmuran bagi umat secara merata karena dilandasi hukum syara' pada berbagai kebijakannya, termasuk di dalamnya kebijakan fiskal. Selama kurun waktu tersebut, umat Islam tidak pernah menggunakan sumber hukum atau kontitusi lain selain dari al-Qur'an, as-Sunnah,

\footnotetext{
${ }^{134}$ Rahmat Kurnia, "Jakarta International Conference of Muslim Intelectual", (Jakarta, 2013).

${ }^{135}$ Dwi Ratnasari, "Sulaiman Al-Qanuni: Sultan Terbesar Kerajaan Turki Usmani," Jurnal Thaqafiyyat, vol. 14, no. 1, (2013): 70-88, http://ejournal.uin-suka.ac.id/adab/thaqafiyyat/article/view/613/pdf_18.

${ }^{136}$ Ratnasari, 71; Roger B. Meriman Meriman, Suleiman the Magnificent, (Cambridge: Harvard Press., 1944).

${ }^{137}$ Standford J. Shaw, History of The Ottoman Empire and Modern Turkey, (Cambridge: Cambridge University Press., 1976), 87; Ismail Ahmad Yaghi, Daulah Ustmaniyah fi at-Tarikh al-Islam al-Hadits, (DMN: Maktabah al-Abikan, n.d.), 33.

${ }^{138}$ Ash-Shalabi, Ad-Daulah Al-Islamiyah, Terj. Samson Rahman,; Ratnasari, "Sulaiman Al-Qanuni: Sultan Terbesar Kerajaan Turki Usmani."

${ }^{139}$ Ratnasari, "Sulaiman Al-Qanuni: Sultan Terbesar Kerajaan Turki Usmani."

${ }^{140}$ M. Umer Chapra, Sistem Moneter Islam, terj. Ikhwan Abidin Basri dari judul asli Towards a Just Monetory System, (Jakarta: Gema Insani Press., 2000), 1.
} 
dan ljma'. Dengan demikian, penerapan kaidah fiqh yang menyatakan "Dimana ada (pelaksanaan) hukum syara' di situ terdapat mashlahat ${ }^{\prime 141}$, dapatlah diyakini sepenuhnya.

\section{Simpulan}

Berdasarkan uraian di atas, penulis dapat menyimpulkan bahwa berbagai bentuk kebijakan Rasulullah SAW mengenai pengelolaan fiskal yang kemudian dilanjutkan Khulafa ar-Rasyidin, merupakan representasi dari prinsip-prinsip belanja publik dalam konteks sosial, politik, ekonomi, dan keamanan, yang manajemennya didasarkan pada prinsip kebijakan anggaran berimbang. Ada pun pendayagunaan instrumen zakat, jizyah, kharaj, ghanimah, wakaf sebagai sumber APBN pada masa itu, menggambarkan dialektika pencapaian misi Islam dalam menciptakan keadilan dan kesejahteraan umat, serta merupakan bentuk kompromi menuju cita-cita ideal ekonomi Islam dalam bingkai maqashid al-syariah menuju visi Islam yang rahmatan lil'alamin. Sejarah telah membuktikan pengelolaan anggaran berlandaskan kebijakan fiskal yang tepat di masa ke-Khalifahan 'Umar ibn 'Abd al-'Aziz (Bani Ummayah), Harun al-Rasyid (Bani Abbasiyah), dan Sulaiman al-Qanuni (Dinasti Ustmani), telah membuat negara Islam menjadi adikuasa yang disegani, baik di bidang politik, ekonomi, sains, maupun di bidang pertahanan.

\section{Daftar Pustaka}

Amalia, Euis. Sejarah Pemikiran Ekonomi Islam Dari Masa Klasik Hingga KontemporerNo Title. Jakarta: Gramata Publishing, 2010.

An-Nawy, Fathiy Syamsuddin Ramadhan. Panduan Lurus Mamahami Khilafah Islamiyyah Manurut Kitab Kuning. Jakarta: Wadi Press., 2013.

Aria, Pingit. "5 Point Penting Dalam Perpu Kebijakan Ekonomi Terkait Covid-19." Artikel katadata.co.id, 2020.

As-Suyuthi. Tarikh Al-Khulafa', Terj, Samson Rahman Dari Judul Asli Tarikh Al-Khulafa',. Jakarta: Pustaka Al-Kautsar, 2000.

Ash-Shalabi. Ad-Daulah Al-Islamiyah, Terj. Samson Rahman,. Jakarta: Pustaka Al-Kautsar, 2012.

Auda, Jasser. Maqasid Al-Shariah as Philosophy of Islamic Law: A System Approach. 1st ed. Herndon, USA: International Institute of Islamic Thought, 2008.

Chapra, M. Umer. Sistem Moneter Islam, Terj. Ikhwan Abidin Basri Dari Judul Asli Towards a Just Monetory System. Jakarta: Gema Insani Press., 2000.

CNN. "Global Economics Gap." Indonesia, 2020.

\footnotetext{
${ }^{141}$ Djazuli, Kaidah-Kaidah Fikih,.
} 
Djazuli, H.A. Kaidah-Kaidah Fikih, Jakarta: Kencana Prenada Media Grup, 2011.

El-Fikri, Syahruddin. "Cara Dinasti Ummayah Dan Abbasiyah Menerapkan Pajak." Artikel Khazanah, 2017.

Erfanie, Sairi. Kebijakan Anggaran Pemerintah. Yogyakarta: Kreasi Wahana, 2005.

Fauzia, Ika Yunia. Etika Bisnis Dalam Islam. Jakarta: Kencana Prenata Media Grup, 2013.

Gampito. "Pemikiran Kebijakan Fiskal Ekonomi Islam." Jurnal JURIS 9, no. 1 (2010): 32-46.

Hamdani, MA. "Sistem Fiskal Dan Inflasi Pada Masa Abu Bakar As-Shiddiq AS." Jurnal Ekonomi Bisnis Sosial INVESTAMA 3, no. 1 (2009): 73-83.

Hidayat, Mohamad. Pengantar Ekonomi Islam. Jakarta: Pusat Komunikasi Ekonomi Syariah, 2009.

Husain, Safarni. "Zakat Penghasilan Sebagai Pengurang Penghasilan Kena Pajak." Jurnal Risalah 6, no. 1 (2010): 6-23.

Kamal, Mustafa. "Wakaf Tunai Menurut Pandangan Fiqh Syāfi'lyah Dan Fatwa Majelis Ulama Indonesia No.2 Tahun 2002 Tentang Wakaf Uang." Jurnal Ilmiah Islam Futura 15, no. 1 (2015): 93-110. https://doi.org/10.22373/jiif.v15i1.56o.

Kara, Muslimin H. Bank Syariah Di Indonesia Analisis Terhadap Pemerintah Indonesia Terhadap Perbankan Syariah. Yogyakarta: Universitas Islam Indonesia Press., 2005.

Karim, Adiwarman A. Ekonomi Islam Suatu Kajian Kontemporer. Jakarta: Gema Insani Press., 2001.

_. Ekonomi Makro Islami. Jakarta: III T Indonesia, 2002.

—. Sejarah Pemikiran Ekonomi Islam. Ed. 3. Jakarta: RajaGrafindo Persada, 2008.

Kemenkeu. "Intervensi Pemerintah Dalam Perekonomian: Bagian I Ringkasan Sejarah." DJKN, 2018.

Kemenlu. "Kebijakan Pemerintah Republik Indonesia Terkait Wabah Covid-19." Artikel Beranda, 2020.

Keyness, John Maynard. The General Theory of Employment, Interest, and Money. 2007th ed. London: Pargrave Macmillan, 2007.

Khaldun, Ibn. Muqaddimah. Kairo, Mesir: Mathba'ah Musthafa Muhammad, n.d.

Killiyah, Lulu. "Sumber Pendapatan Ekonomi Masa Rasulullah." Artikel Hima Prodi ESY STAIS, 2018.

Kunaifi, Aang. "Telaah Kritis Kebijakan Fiskal." In Proceeding AICIED. AICIED, 2018.

Kuper, Adam; Kuper, Jessica. The Social Science Encyclopedia. 2nd Ed. New York: 
Routledge, 2001.

Kurnia, Rahmat. "Jakarta International Conference of Muslim Intelectual." Jakarta, 2013.

M. Faried Wijaya, M. Faried. Ekonomikamakro. Yogyakarta: BPFE, 2000.

Marasabessy, Ruslan Husein. "Analisasi Pola Distribusi Zakat Pada Masa Daulah Umayyah Dan Abbasiyah." Jurnal Asy- Syukriyyah 18 (2017): 132-50.

Menita, Herza Ayu. "Pemikiran Abdul Mannan Tentang Ekonomi Islam." Jurnal Al-Intaj 3, no. 1 (2017): 216-38.

Meriman, Roger B. Meriman. Suleiman the Magnificent. Cambridge: Harvard Press., 1944.

Misanam, et. al., Munrokhim. Ekonomi Islam. Jakarta: Rajawali Press., n.d.

Moffat, Mike. "The Government's Role in Economy." Article, 2017.

Munte, Abdul Karim. "Sejarah Baitul Mal Pada Masa Awal Islam." Beranda Khazanah, bincangsyariah.com, 2019.

Murtadho, Ali. "Konsep Fiskal Islam Dalam Perspektif Historis." Jurnal Economaca IV, no. 1 (2013): 33-50.

Mustafa. "Sistem Ekonomi Keuangan Publik Berbasis Zakat." Jurnal Madani vol 4, no. 1 (2014): 28-42.

Musyaddad, Ahmad. "KEBIJAKAN FISKAL DI MASA PEMERINTAHAN ABU BAKAR ASHSHIDDIQ Ahmad Musyaddad." Ekonomi Islam 4, no. 2 (2013): 217, 218,.

Nainggolan, Edward UP. "Kebijakan Fiskal Dan Moneter Menghadapi Dampak Covid-19." Artikel DKJN Kemenkeu, 2020.

Nasution, Mustafa Edwin et. al. Pengenalan Ekslusif Ekonomi Islam. Jakarta: Kencana Prenada Media Grup, 2007.

Novirin. Ekonomi Moneter, Buku 1. Yogyakarta: BPFE Yogyakarta, 1993.

Oemar Moechthar. "Kedudukan Negara Sebagai Pengelola Warisan Atas Harta Peninggalan Tak Terurus Menurut Sistem Waris Burgerlijk Wetboek." Jurnal Yuridika FH Unair 32, no. 2 (2017): 280-309.

Pass, Christopher; Lowes, Bryan. Collins Dictionary of Economics, Terj. Tumpal Rumapea \& Posman Haloho, "Kamus Lengkap Ekonomi."Ed. 2. Jakarta: Erlangga, 1994.

Priharto, Sugi. "Mengenal Lebih Jauh Kebijakan Fiskal." Artikel, 2020.

Qol'ahji, Muh. Rawwas. Sirah Nabawiyah Sisi Politis Perjuangan Rasulullah SAW, Terj. Tim Al-Izzah Dari Judul Asli Sirah Nabawiyah. Bogor: Al-Azhar Press., 2013.

Rahmawati, Lilik. "Sistem Kebijakan Fiskal Modern Dan Islam." OECONOMICUS Journal of 
Economics 1, no. 1 (2016): 21-48.

Ratnasari, Dwi. "Sulaiman Al-Qanuni: Sultan Terbesar Kerajaan Turki Usmani." Jurnal Thaqafiyyat 14, no. 1 (2013): 70-88.

Sabzwari. "Economic and Fiscal System during Khulafa Ar-Rasyidin." Jur

nal Banking, Karachi 2 (n.d.).

Saddam, Muhammad. Ekonomi Islam. Jakarta: Gramedia, 2002.

Samuelson; Nordhaus, William D. Makroekonomi, Terj. Haris Munandar Dari Judul Asli Economics. 4th ed. Jakarta: Jakarta: Erlangga, 1997.

Sanandaji, Nima. "Why the Laffer Curve Should Really Be Called the 'Khaldun Curve."' Artikel CAPX, 2018.

Sauri, Supian; Mutirrahman. "Pajak Dan Zakat Ditinjau Dari Trilogi Fungsi Kebijakan Fiskal." In Seminar Nasional Dan Call For Papers Ekonomi Syariah"Indonesia Sebagai Kiblat Ekonomi Syariah," 252-63. Malang: Perpustakaan UM, 2015.

SCTV. "Liputan6 Sore, Berita." Indonesia, 2020.

Sharma, B. Lal. Economic Ideas in Ancient India before Kautilya. New Delhi: Ramchand Vidya Bhawan, 1987.

Shaw, Standford J. History of The Ottoman Empire and Modern Turkey. Cambridge: Cambridge University Press., 1976.

Siddharta, Hendrawinata Eddy. "Jelaskan Kebijakan Fiskal Di Indonesia." Berita, 2015.

Smith, Adam. The Wealth of Nations. Vol. 1. London: W. Strahan \& W. Cadell, 1776.

Sofiani, Ratna Dewi. "Wakaf Tunai: Instrumen Alternatif Kemakmuran Umat," 2003.

Sukirno, Sadono. Makroekonomi Teori Pengantar. Ed. 3. (Jakarta: RajaGrafindo Perkasa, 2010.

Suparmoko, M. Keuangan Negara Dalam Teori Dan Praktik. Yogyakarta: BPFE-Yogyakarta, 1997.

Suprayitno, Eko. Ekonomi Islam Pendekatan Ekonomi Makro Islam Dan Konvensional. Yogyakarta: Graha Ilmu, 2005.

Suwito. Sejarah Sosial Pendidikan Islam. Jakarta: Kencana Prenada Media Grup, 2015.

Suyanto, Mohammad. "Kebijakan Fiskal Pada Masa Rasulullah S.A.W. (1)." Jurnal Universitas Amikom Yogyakarta, 2006.

Syamsudin, Muhammad. "Pemikiran Abu-Yusuf Soal Ekonomi Negara Dalam Kitab AlKharraj." Artikel Pustaka Beranda Islam Indonesia, 2019. 
Tadjuddin, Nilawati, and Alif Maulana. "Kebijakan Pendidikan Khalifah Harun Ar-Rasyid." Al-Tadzkiyyah: Jurnal Pendidikan Islam 9, no. 2 (2018): 325-46. https://doi.org/10.24042/atjpi.vgi2.3633.

Tafsirweb. "Ayat Zakat." Artikel Tafsirweb, n.d.

Wardhana, Wisynu, and Djoni Hartono. "Instrumen Stimulus Fiskal: Pilihan Kebijakan Dan Pengaruhnya Terhadap Perekonomian Fiscal Stimulus Instruments: Policy Options and the Effect on the Economy." Jurnal Ekonomi Dan Pembangunan Indonesia 12, no. 2 (2012): 107-15.

Widya Utami, Novia. "Pengertian Kebijakan Fiskal Dan Tujuannya." Jurnal Entrepreneur, 2020.

Wikipedia. "Kebijakan Fiskal." Ensiklopedia, n.d.

Yaghi, Ismail Ahmad. Daulah Ustmaniyah Fi At-Tarikh Al-Islam Al-Hadits. DMN: Maktabah al-Abikan, n.d. 
Asy-Syari'ah (P-ISSN: 2086-9029 E-ISSN: 2654-5675) is a periodical scientific journal that publishes various results of studies and research, literature review, and other scientific works whose scope covers the field of Islamic law/sharia, law and society in monodisciplinary, interdisciplinary, and multidisciplinary manners. The journal aims to expand and create innovative concepts, theories, paradigms, perspectives and methodologies in the above said scope. The Journal is published twice a year (june and december) by Faculty of Shariah and Law, Sunan Gunung Djati State Islamic University Bandung in collaboration with Asosiasi Sarjana Syariah Indonesia (ASSYI).

\section{EDITORIAL OFFICE:}

Fakultas Syariah dan Hukum UIN Sunan Gunung Djati Bandung J1. Raya A.H. Nasution No. 105 Cibiru Kota Bandung, 40614

Tlp/Fax: +022-7802278 Faks. 022-7802278

Website http://journal.uinsgd.ac.id/index.php/asy-syariah/index

E-mail: Jurnalasy-syariah@uinsgd.ac.id 